\title{
Timing of diagenesis and very low-grade metamorphism in the eastern sector of the Sierra de Cameros (Iberian Range, Spain): a U-Pb SHRIMP study on monazite
}

\author{
P. Del Río, ${ }^{1}$ L. Barbero, ${ }^{1}$ P. Mata ${ }^{1}$ and C. M. Fanning ${ }^{2}$ \\ ${ }^{1}$ Dpto. Ciencias de la Tierra, Facultad de Ciencias del Mar y Ambientales, Universidad de Cádiz, 11051, Puerto Real, Cadiz, Spain; ${ }^{2}$ Research \\ School of Earth Sciences, Australian National University, Canberra ACT 0200, Australia
}

\begin{abstract}
The Sierra de Cameros is an intracontinental orogen and represents the north-western part of the Iberian Range in Northern Spain. It comprises a thick sequence of syn-rift continental sediments (mainly sandstones and carbonates) deposited during lower Cretaceous times. A unique characteristic of the Sierra de Cameros in relation to the rest of the Iberian Range is the presence of low-grade metamorphism in certain parts of the basin, an event that predates basin inversion. This paper describes the presence, textural relationships and geochemical aspects of authigenic and/or metamor-
\end{abstract}

phic monazite within different lithologies from the deepest parts of the basin. Sensitive high resolution ion microprobe (SHRIMP) U-Pb dating of monazite records the presence of two age populations: the first with ${ }^{206} \mathrm{~Pb} /{ }^{238} \mathrm{U}$ ages ranging from 122 to $116 \mathrm{Ma}$ which is considered as diagenetic in origin, whilst the second is dated at $99 \pm 2 \mathrm{Ma}$ and postdates the metamorphic climax.

Terra Nova, 21, 438-445, 2009

\section{Introduction}

In recent years, there has been an increasing interest in dating monazite formed under different temperature and fluid conditions (e.g. Rasmussen et al., 2007; Kempe et al., 2008; Janots et al., 2009). Monazite has a number of characteristics that make it a suitable mineral for $\mathrm{U}-\mathrm{Pb}$ dating. These include: (a) high $U$ contents (e.g. Parrish, 1990); (b) it usually does not incorporate lead during crystallization (Montel et al., 1996); (c) the $\mathrm{U}-\mathrm{Pb}$ system exhibits a high closure temperature $\left(T^{\circ}{ }_{C}>900{ }^{\circ} \mathrm{C}\right.$; Cherniak et al., 2004); (d) it can be found in a variety of lithologies (Spear and Pyle, 2002); (e) it forms under different metamorphic conditions including the high temperature part of the diagenesis (Milodowski and Zalasiewicz, 1991; Lev et al., 1998; Wilby et al., 2007), prehnite-pumpellyite facies (Cabella et al., 2001; Rasmussen et al., 2001, 2005), greenschist facies (Frantz et al., 1996) and amphibolite-granulite facies (e.g. Smith and Barreiro, 1990; Rubatto et al., 2001; Wing et al., 2003; Janots

Correspondence: Pedro Del Río Bermejo, Dpto. Ciencias de la Tierra, Facultad de Ciencias del Mar y Ambientales, Universidad de Cádiz, 11051, Puerto Real, Cadiz, Spain. Tel.: int-34-956-016596; e-mail: pedro.bermejo@uca.es et al., 2008). In low-grade metamorphic rocks, few geochronometers can be applied, so studies of the genesis and dating of newly formed monazite in common lithologies such as marls and metapelites is a powerful technique in constraining the tectonothermal evolution of sedimentary basins (e.g. Rasmussen et al., 2005). A preliminary attempt to date the monazites of the Cameros Basin by electron microprobe analysis following the method of Montel et al. (1996) was unsuccessful because of the low amount of radiogenic $\mathrm{Pb}$ accumulated since the metamorphic peak. In this work, we present SHRIMP U-Pb data of monazite from metapelites and sandstones of the Cameros Basin. We demonstrate how such in situ analyses constrain the time of monazite growth at different stages of progressive burial and low-grade metamorphic episodes of the basin.

\section{Geological framework}

The Sierra de Cameros constitutes part of the northwestern zone of Iberian Range. It is bounded by two Tertiary basins: the Ebro basin to the north and the Duero basin to the south (Fig. 1). Two Palaeozoic massifs, the Sierra de la Demanda and the Sierra del Moncayo are located to the northwest and to the southeast respectively (Fig. 1). The Sierra de Cameros was an intra- continental basin formed during the Mesozoic as a consequence of an extensional period related to the opening of the North Atlantic Ocean and Bay of Biscay. The structure of the basin shows a half-graben geometry controlled by a system of E-W/NWSE trending listric faults that were the result of reactivation of previous Variscan faults during Mesozoic extension. Tectonic inversion of the basin was related to the Alpine orogeny; during the Eocene, the Sierra de Cameros was thrusted onto the Ebro Basin, and also over the Variscan basement (Fig. 1)

In metapelitic rocks, Al-rich mineral assemblages containing chloritoid are observed in the deepest part of the basin. The assemblage is composed of quartz + chlorite + muscovite + paragonite + chloritoid \pm calcite \pm albite. Mata and López-Aguayo (2000) and Mata and Barbero (2005) first described newly formed monazite, allanite, xenotime, zircon, apatite, florencite and bastnasite in the Cameros Basin. Temperatures of $350{ }^{\circ} \mathrm{C}$ and pressures under 1-2 kbar were proposed by Mata et al. (2001) on the basis of the reaction

2 pyrophillite + amesite $=4$ chloritoid +6 quartz $+2 \mathrm{H}_{2} \mathrm{O}$

To achieve low-grade metamorphic conditions and in the absence of 


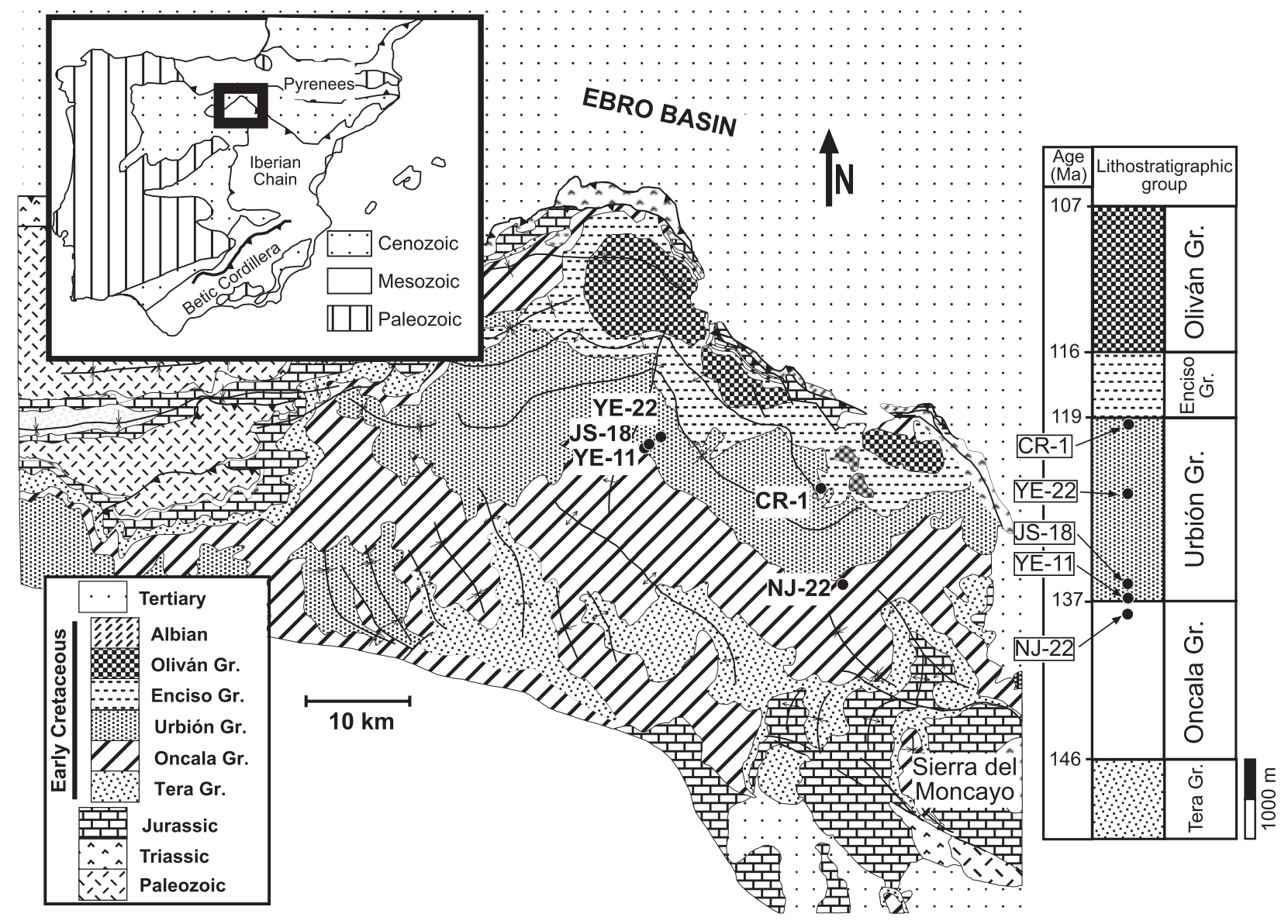

Fig. 1 Map of study area showing the location of samples studied in this work. Inset shows a schematic geological map of the Iberian Peninsula showing the location of the study area within the context of the Iberian plate. The stratigraphic column to the right shows the estimated thickness of the different groups into which the Lower Cretaceous series of the area are commonly divided (e.g. Tischer, 1966; Casas-Sainz and Gil-Imaz, 1998). The tentative position of the samples within the stratigraphic column and the depositional ages used in this work (based on Mas et al., 1993) are also shown.

magmatic activity in the area, an anomalously high geothermal gradient up to $70-80^{\circ} \mathrm{C} / \mathrm{km}$ is required (Mas et al., 1993; Mata et al., 2001; Del Río et al., 2009). Several hypotheses proposed to explain this high geothermal gradient include crustal thinning (Mata et al., 2001), the presence of hydrothermal fluids (Mantilla-Figueroa et al., 1999), the blanketing effect of low conductivity sediments, or a combination of all these mechanisms. Goldberg et al. (1988) and Casquet et al. (1992) presented preliminary $\mathrm{K}-\mathrm{Ar}$ and $\mathrm{Ar}-$ Ar data on illites of the Cameros Basin rocks in the range of 102 to 98 and 108 to 86 Ma respectively.

\section{Methodology}

Four samples from the Lower Cretaceous sediments (Valanginian-Middle
Aptian; Mas et al., 1993) located towards the central part of the basin were selected for dating: YE-11, JS-18 (shale and sandstone from the bottom of the so-called Urbión group), YE-22 (siltstones from the middle part) and CR-1 (black shale from the top). Sample NJ-22 is a siltstone from the top of the Oncala group (Fig. 1) which was not dated but previously selected because of the presence of florencite crystals along with chloritoid. Dating was carried out in situ within polished thin sections of the rock samples to have the maximum textural control on the dated phase. Furthermore, because of the irregular and poikilitic grain morphology and small size (usually less than $100 \mu \mathrm{m}$ ), it is not possible to carry out normal mineral separation procedures. High magnification BSE images of the grains to be analysed
(Fig. 2) were made using a SEM Cambridge $\mathrm{S} 360$. The $\mathrm{U}-\mathrm{Pb}$ dating was performed using SHRIMP-II at the Research School of Earth Sciences, Canberra, (Australia) following the methods described in Williams (1998, and references therein). U-Pb ratios were calibrated against reference monazite 44069 (424.9 Ma; Aleinikoff et al., 2006), and the data reduced using the SQUID Excel Macro of Ludwig (2001). Tera-Wasserburg concordia plots and regression lines were made using ISOPLOT/EX (Ludwig, 2003). Chemical analyses of the monazites dated were obtained using an electron microprobe (Jeol Superprobe JXA-8900-M) at Complutense University of Madrid using operating conditions of $20 \mathrm{kV}, 150 \mathrm{nA}, 2-5 \mu \mathrm{m}$ beam diameter and a ZAF correction procedure. 

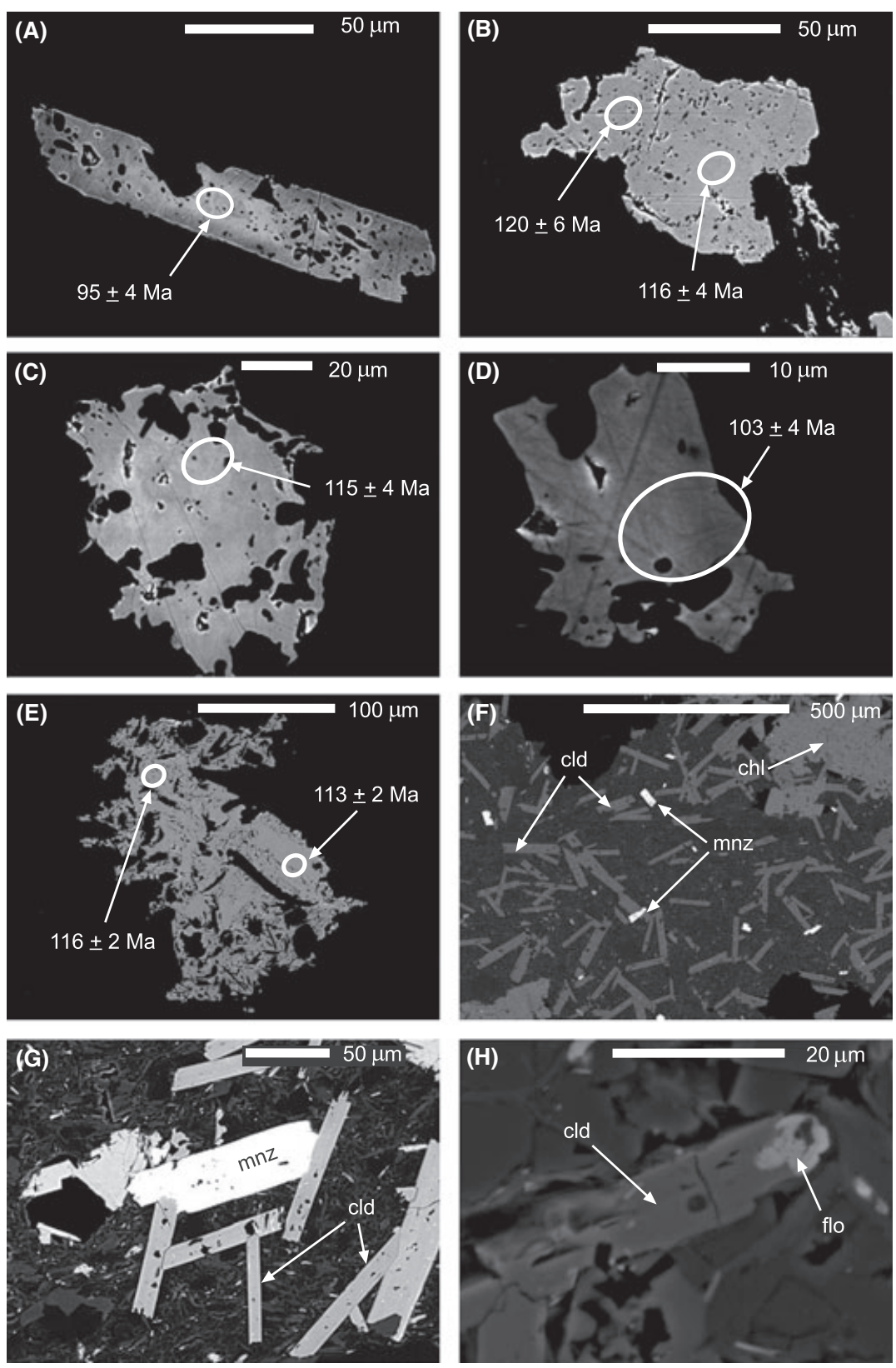

Fig. 2 BSE images of a selection of monazite crystals showing the location of the analysis spots and their $\mathrm{U}-\mathrm{Pb}$ age (errors are $1 \sigma$ ). It can be observed that compositional zoning is almost absent. (A) Idioblastic monazite grains with quartz and Ti oxides inclusions in sample YE-11. (B) Anhedral monazite between quartz grains from sample JS-18. (C) and (D) Small monazite patches in a phyllosilicate matrix from sample YE-22. (E) Monazite crystals as irregular patches with several quartz and mica inclusions included in a matrix rich in organic matter from sample CR-1. (F) BSE image of sample YE-11 showing the mutual relation between the idioblastic chloritoid and monazite crystals. (G) Idioblastic monazite crystal crosscutting a chloritoid prism in sample YE-11. (H) BSE image from sample NJ-22 with chloritoid crystal partially replaced by florencite. chl, chlorite; cld, chloritoid; flo, florencite; mnz, monazite.

\section{Results}

Three different types of monazite can be distinguished in the Cameros Basin monazite which is present as round grains; (b) authigenic/metamorphic monazite exhibiting a xenoblastic tex-
(Mata and Barbero, 2005): (a) detrital ture among the phyllosilicates of the matrix and generally including several phases such as quartz, phyllosilicates and Ti oxides (Fig. 2B-E); (c) idioblastic authigenic/metamorphic monazite with prismatic habit resembling the habit of the chloritoid crystals (Fig. 2A, F and G).

Chemical analyses reveal that all monazite grains are Ce-rich varieties, with low $\mathrm{Th}$ and $\mathrm{Si}$ contents (Table S1). Two different groups of $\mathrm{Ca}-\mathrm{Th}-\mathrm{U}$-rich and -poor monazite can be distinguished (Fig. 3A) their differences in composition being related to a brabantitic-type substitution (joint entry of $\mathrm{Th}$ and $\mathrm{Ca}$ replacing REE; Fig. 3B). Chondritenormalized REE patterns are similar in all samples. They show negative fractionation patterns typical for metamorphic monazite (Spear and Pyle, 2002). However, subtle differences in the normalized REE patterns exist (Fig. 4), although there is no clear relationship between REE contents from the Th-rich and Th-poor groups. REE ratio plots, such as Sm vs. La or Y vs. HREE show compositions close to those typical for lowgrade metamorphic monazite (Frantz et al., 1996) (Fig. 3C-D).

The $\mathrm{U}-\mathrm{Pb}$ isotope dating results are summarized in Table S2 and plotted on Tera-Wasserburg concordia plots (Fig. 5). The data from sample YE-11 (Fig. 5A) have significant dispersion in calculated radiogenic ${ }^{206} \mathrm{~Pb} /{ }^{238} \mathrm{U}$ ages. A discordia regression line fitted to all 13 analyses has excess scatter $(\mathrm{MSWD}=8.1)$ with a concordia lower intercept of $99 \pm 13 \mathrm{Ma}$.

For sample JS-18, 13 of 15 areas analysed define a moderately fitted discordia with a concordia lower intercept at $119 \pm 3 \mathrm{Ma}$ (MSWD = 2.5; Fig. 5B). Two other areas analysed lie to the left of the best fit line and are interpreted to represent older inherited monazite components.

For sample CR-1 (Table S2, Fig 5C), a regression line fitted to all 14 analyses has excess scatter with a lower intercept at $116 \pm 4 \mathrm{Ma}$ (MSWD = 6.6). If one considers only the more radiogenic end members from this data-set, the regression line intercept concordia at $112 \pm 5 \mathrm{Ma}(\mathrm{MSWD}=$ 2.9) and this provides the best estimate for the time of crystallization of the newly formed monazite in this sample. 

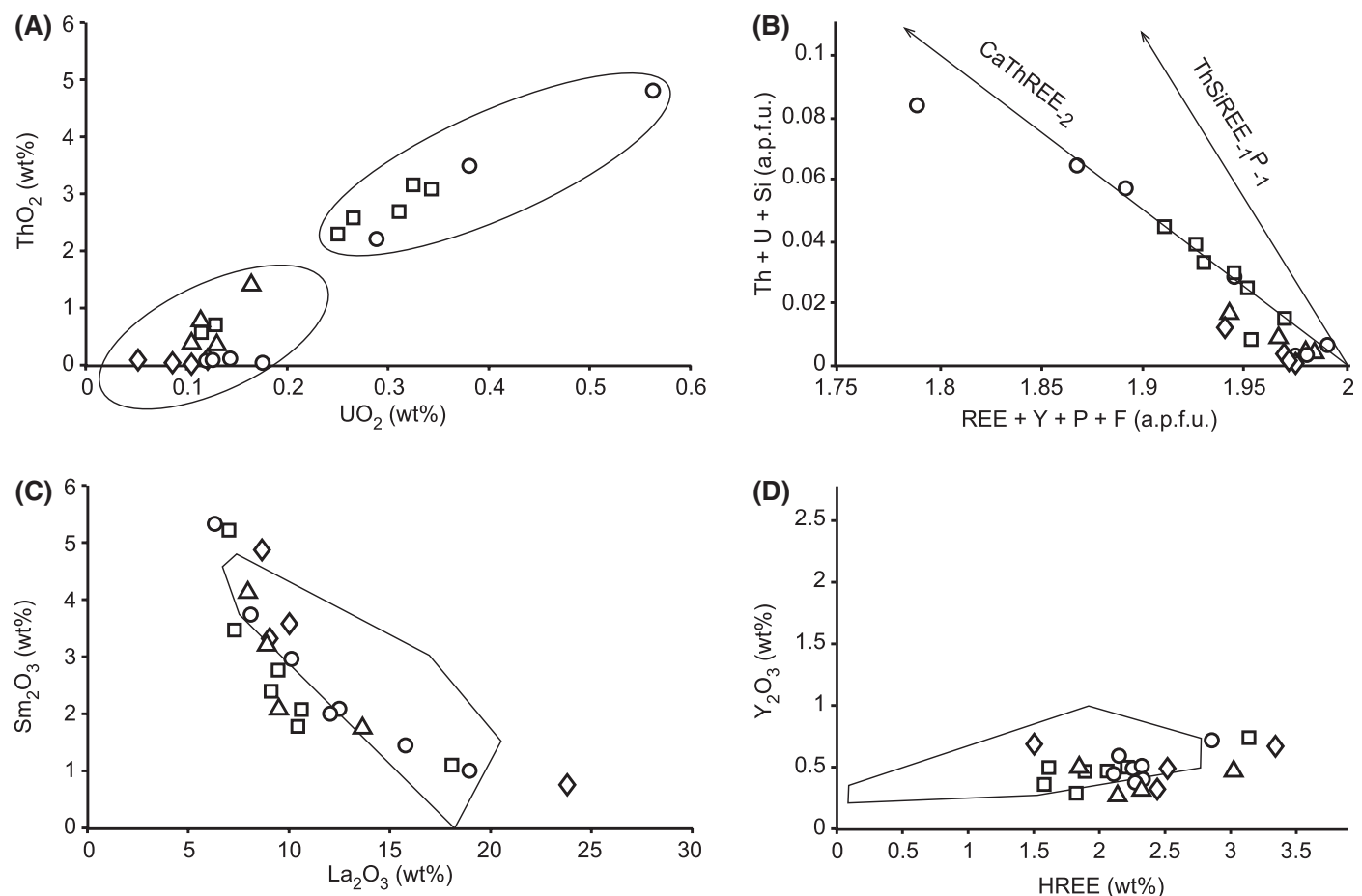

Fig. 3 (A) $\mathrm{ThO}_{2}$ vs. $\mathrm{UO}_{2}$ diagram in which the Th-rich and Th-poor groups can be distinguished. (B) $(\mathrm{Th}+\mathrm{U}+\mathrm{Si})$ vs. $(\mathrm{REE}+\mathrm{Y}+\mathrm{P}+\mathrm{F})$ diagram in atoms per unit cell, where the brabantitic (left arrow) and huttonitic (right arrow) substitutions are represented (Förster, 1998). (C) $\mathrm{Sm}_{2} \mathrm{O}_{3}$ vs. $\mathrm{La}_{2} \mathrm{O}_{3}$ diagram in which subtle differences in light REE fractionation are envisaged. (D) $\mathrm{Y}_{2} \mathrm{O}_{3}$ vs. total amount of HREE diagram. In $\mathrm{C}$ and $\mathrm{D}$, the outlined area indicate typical compositions of low-grade metamorphic monazite after Frantz et al. (1996); Triangles represent data from YE-11, diamonds from JS-18, squares from YE-22, and circles from CR-1.

The data for sample YE-22 show a greater range in calculated radiogenic ${ }^{206} \mathrm{~Pb} /{ }^{238} \mathrm{U}$ ages than the other samples discussed above (Table S2, Fig. 5D). A single discordia regression line cannot be fitted to all 14 grains analysed (Fig. 5D). However, the data can be arbitrarily divided into two groups; an older grouping of 5 analyses with an intercept at $107 \pm 4 \mathrm{Ma}$ (MSWD $=0.6$ ) and a younger dominant group of 9 analyses with an intercept at $99 \pm 2 \mathrm{Ma}$ (MSWD = 2.0).

\section{Discussion}

Monazite grains from sample JS-18 at the bottom of Urbión group (Fig. 1) have a concordia lower intercept age of $119 \pm 3 \mathrm{Ma}$. At that time, the deposition of the overlying Enciso group (Aptian) occurred, with the thickness of sediments over sample JS-18 estimated to be about 1.6$3.2 \mathrm{~km}$ (sediment thickness calculated on the basis of Casas-Sainz and GilImaz, 1998 and Gil-Imaz, 2001).
Assuming a maximum geothermal gradient of about $41{ }^{\circ} \mathrm{C} / \mathrm{km}$ for the extensional stage (based on palaeotemperatures of fluid inclusions in tension gashes; Mata et al., 2001), the temperature reached was $66-131{ }^{\circ} \mathrm{C}$. As these temperatures correspond to late diagenesis conditions, it is likely that the first period of monazite growth corresponds to diagenetic rather than to low-grade metamorphic conditions. Monazite formation under similar low-grade conditions has been observed in other locations by several authors (Milodowski and Zalasiewicz, 1991; Evans and Zalasievizc, 1996; Lev et al., 1998; Evans et al., 2002).

As stated by Mata et al. (2001), the geothermal gradient may have increased from 41 to $70{ }^{\circ} \mathrm{C} / \mathrm{km}$ to reach a thermal peak of $\sim 350{ }^{\circ} \mathrm{C}$ during middle Albian times, that is, after the whole sequence of syn-rift sediments were deposited. Similar calculations to those made for JS-18 can be performed for samples YE-22 (older population) and $\mathrm{CR}-1$, the range of temperatures being $123-273{ }^{\circ} \mathrm{C}$ and 49-210 ${ }^{\circ} \mathrm{C}$ respectively, taking into account the rise in geothermal gradient for the youngest age range, which locates the formation of monazite for these samples between diagenetic and low-grade metamorphic conditions. Monazite grains from sample YE-11 show an idioblastic habit resembling that of the surrounding chloritoid crystals (Fig. 2F and G). As chloritoid belongs to the metamorphic peak paragenesis, the idioblastic textural appearance of monazite (Fig. 2F and $\mathrm{G})$ suggests that it must have grown either synchronously or later than chloritoid. The possible replacement of chloritoid by monazite should be allochemical and no conclusive textures such as partial replacements have been observed. Notwithstanding, partial replacement of other REE phosphate as is the case of florencite after chloritoid occurs in the metapelites from the Cameros Basin (Fig. 2H), which opens the possibility for a two-stage replacement process: first, the chloritoid could be replaced by 
(A)

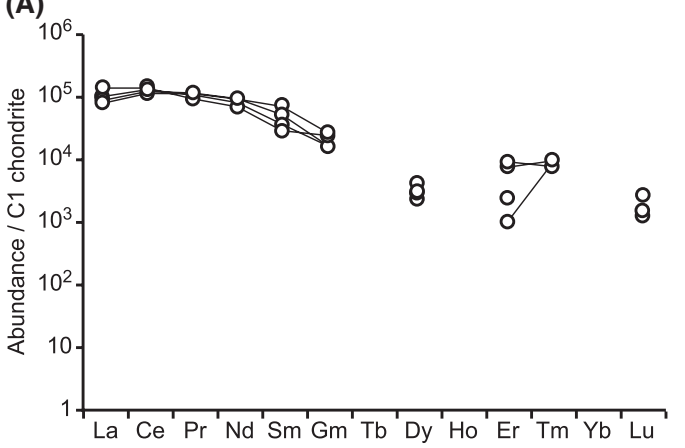

(C)

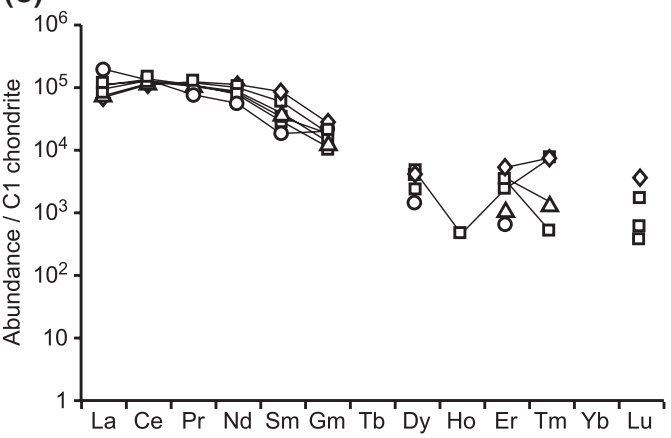

(B)

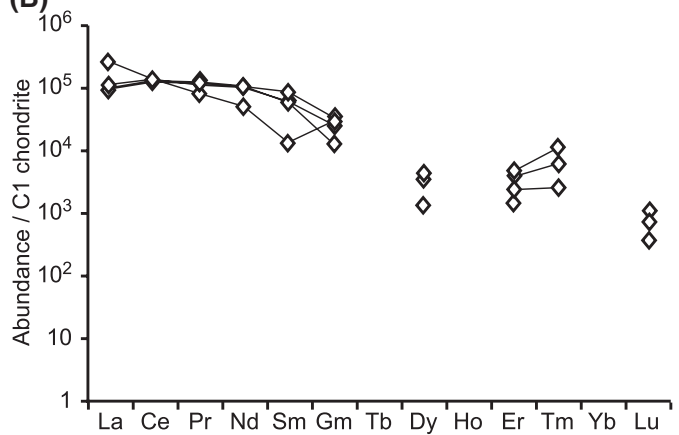

(D)

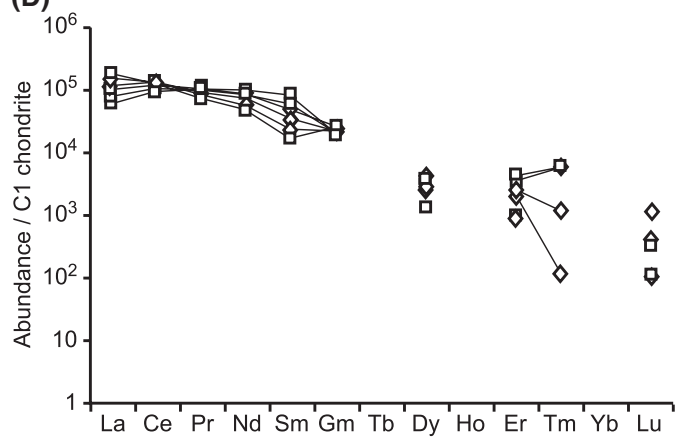

Fig. 4 Chondrite-normalized (Masuda et al., 1973) REE patterns of the dated monazites: (A) YE-11; (B) JS-18; (C) YE-22; (D) CR-1. Squares represent data of monazites with old ages (122-109 Ma) and from the Th-rich group; diamonds represent Th-poor monazites with old ages; triangles represent Th-rich monazites with young ages (106-90 Ma); circles represent Th-poor monazites with young ages.
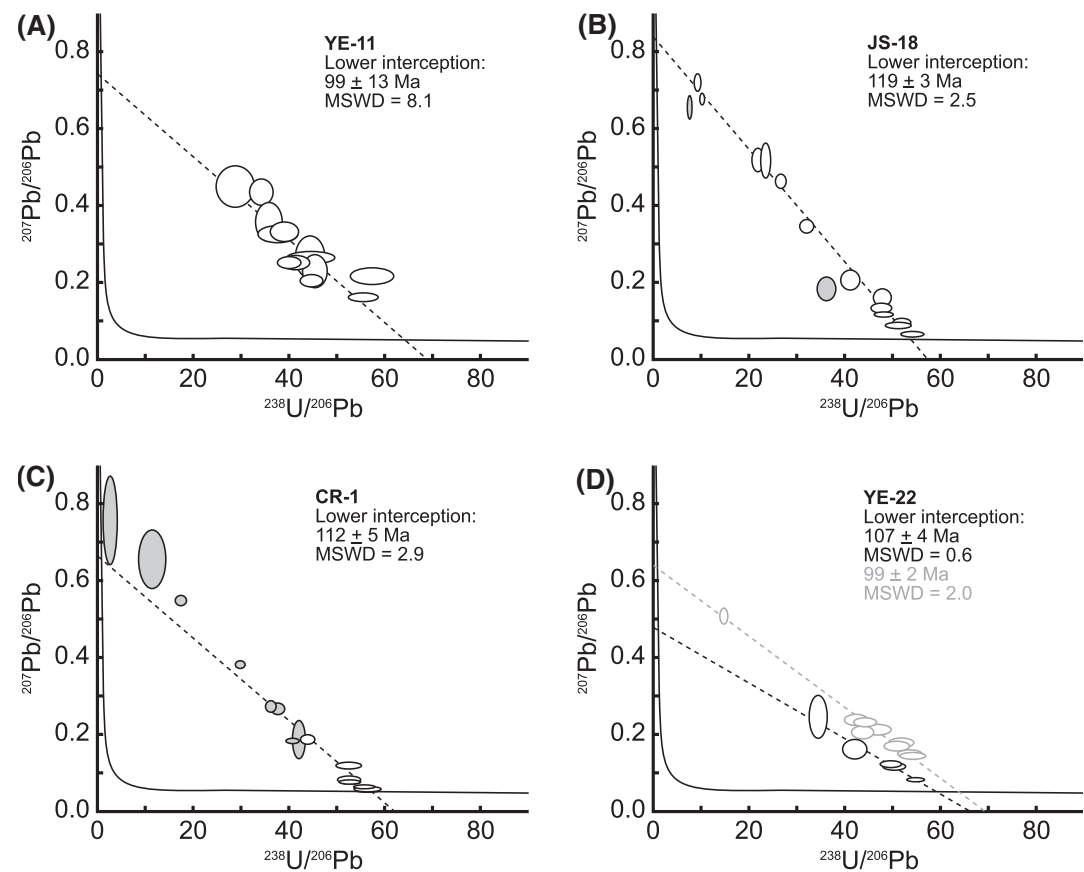

Fig. 5 Tera-Wasserburg diagrams for samples, YE-11 (A), JS-18 (B), CR-1 (C) and YE-22 (D). Ellipses show $2 \sigma$ errors. Grey filled ellipses represent data which were no considered in the regression and grey lined and white filled ellipses represent the youngest age population in sample YE-22. Plots and regression lines were calculated using ISOPLOT/EX software (Ludwig, 2003). florencite and subsequently this could be substituted by monazite (Fig. 2H).

The reaction to form florencite after chloritoid has not been described elsewhere, but similar reactions involving the destruction of chlorite and apatite to form monazite were proposed by Lanzirotti and Hanson (1996). Examples of monazite growing after florencite have been described by Sawka et al. (1986) as result of chemical weathering and more recently by Gabudianu Radulescu et al. (2009) at higher-pressure metamorphic conditions. However, in our case, no textural evidence of this two-stage reaction has been found. A second possibility to explain monazite forming after chloritoid could involve the presence of allanite, as has been evidenced in other localities (Pan et al., 1993; Pan, 1997; Bollinger and Janots, 2006; Krenn and Finger, 2007). In our study we have not found allanite in the Al-rich paragenesis described above, nor any textural evidence relating to the presence of chloritoid and allanite in the metapelitic rocks of the Cameros Basin. 


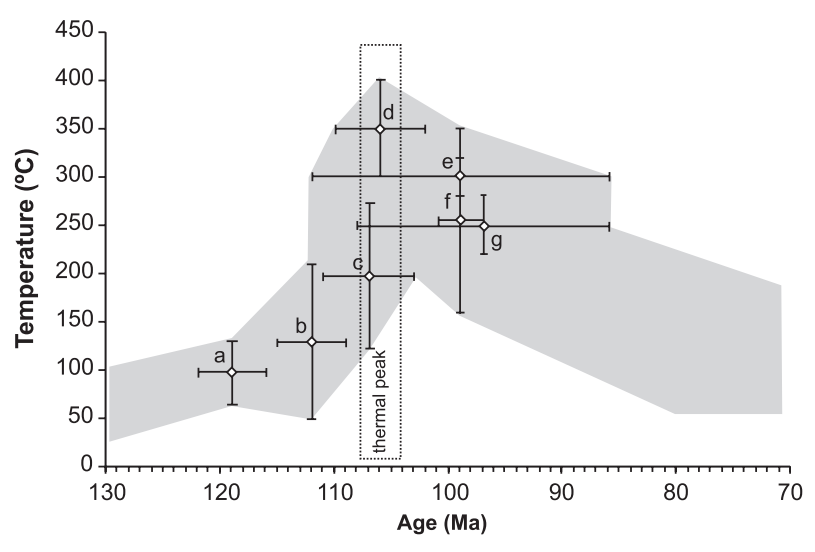

Fig. 6 Schematic summary of the thermal evolution of Cameros Basin. Monazite ages are plotted with their supposed formation temperature. (a) JS-18 U-Pb age; (b) CR-1 $\mathrm{U}-\mathrm{Pb}$ age; (c) YE-22 old age population; (d) range of age and temperature for the metamorphic peak; (e) YE-11 U-Pb age; (f) YE-22 young age population; (g) K-Ar age of illites by Casquet et al. (1992). The deduced age range for the metamorphic peak is plotted as dashed boxes.

Although the U-Pb ages obtained in sample YE-11 show a large dispersion $(99 \pm 13 \mathrm{Ma})$, a growth age younger than $106 \mathrm{Ma}$ would be reasonable because it represents the end of the rifting period, when the geothermal gradient reached its maximum. A period of monazite formation after the metamorphic climax coincides with the dominantly young population recorded in sample YE-22 $(99 \pm 2 \mathrm{Ma})$ and also with the previous $\mathrm{K}-\mathrm{Ar}$ ages obtained in illites (108-86 Ma) by Casquet et al. (1992). In this work, the in situ SHRIMP analyses are found to record geologically significant data, when monazite grains are difficult to separate and have low concentrations of $U$ and radiogenic $\mathrm{Pb}$, i.e. below the detection limits of EMPA.

\section{Conclusions}

The metapelitic rocks of the Cameros Basin contain monazite that formed under late-diagenesis to low-grade metamorphic conditions. The first period of monazite growth occurred during Aptian times in rocks from the deepest part of the basin, at the bottom of the Urbión group. Following progressive burial during lower Cretaceous times, xenoblastic monazite continues to form. SHRIMP $\mathrm{U}-\mathrm{Pb}$ monazite dating shows that during the metamorphic climax of the area, idioblastic monazite crystals formed at ages close to 106-86 Ma.
Textural relationships between chloritoid and idioblastic monazite indicate that both minerals formed at the same time and at temperatures around $350{ }^{\circ} \mathrm{C}$ as reported by Mata et al. (2001). This event is coeval with the end of the rifting stage (Fig. 6). A second generation of monazite grew after the metamorphic climax which stresses the importance of a detailed study of textural relationships between the different phases to successfully interpret their time of formation. This work demonstrates that in situ $\mathrm{U}-\mathrm{Pb}$ dating of authigenic and/or metamorphic monazite using an ion microprobe (SHRIMP) is important if one is to unravel complex diagenetic and low metamorphic processes, even when conditions for dating are not ideal (small size of crystals, relatively young ages, presence of inclusions, etc). The high analytical uncertainty of the data obtained is counterbalanced by the precise knowledge of the textural relationships between the monazite and the different phases of the metamorphic paragenesis.

\section{Acknowledgements}

This work was funded by the research projects BTE2002-04168-C03-02 of Spanish Ministry of Science and Technology and CSD2006-0041 "TOPO-IBERIA" inside the CONSOLIDER-INGENIO 2010 program. This work is part of the objectives of research groups PAI RNM-160 and RNM-328 of the Junta de Andalucía. We also thank Prof. I. Gil-Ibarguchi for the preliminary EMPA data and E. Janots, C. Brime and M. Rahn for their constructive revision which greatly improved this paper.

\section{References}

Aleinikoff, J.N., Schenck, W.S., Plank, M.O., Srogi, L.-A., Fanning, C.M., Kamo, S.L. and Bosbyshell, H., 2006. Deciphering igneous and metamorphic events in high-grade rocks of the Wilmington Complex, Delaware: Morphology, cathodoluminescence and backscattered electron zoning, and SHRIMP U-Pb geochronology of zircon and monazite. Geol. Soc. Am. Bull., 118, 39-64.

Bollinger, L. and Janots, E., 2006. Evidence for Mio-Pliocene retrograde monazite in the Lesser Himalaya, far western Nepal. Euro. J. Min., 18, 289-297.

Cabella, R., Lucchetti, G. and Marescotti, P., 2001. Authigenic monazite and xenotime from pelitic metacherts in pumpellyite-actinolite-facies conditions, Sestri-Voltaggio zone, central liguria, Italy. Canad. Mineral., 39, 717-727.

Casas-Sainz, A.M. and Gil-Imaz, A., 1998. Extensional subsidence, contractional folding and thrust inversion of the Estern Cameros Massif, northern Spain. Geol. Runds., 86, 802-818.

Casquet, A., Galindo, C., GonzálezCasado, J.M., Alonso, A., Mas, R., Rodas, M., García, E. and Barrenechea, J.F., 1992. El metamorfismo en la cuenca de los Cameros. Geocronología e implicaciones tectónicas. Geogaceta, 11, 22-25.

Cherniak, D.J., Watson, B.E., Grove, M. and Harrison, M.T., 2004. Pb diffusion in monazite: A combined RBS/SIMS study. Geochim. Cosmochim. Acta, 68, 829-840.

Del Río, P., Barbero, L. and Stuart, F., 2009(in press). Exhumation of the Sierra de Cameros (Iberian Range, Spain): constraints from low temperature thermochronology. In: Thermochronological Methods: from Paleotemperature Constraints to Landscape Evolution Models (F. Lisker, B. Ventura and U.A. Glasmacher, eds). Geol. Soc. London Spec. Publ., 324, 1-13.

Evans, J. and Zalasievizc, J., 1996. U-Pb, $\mathrm{Pb}-\mathrm{Pb}$ and $\mathrm{Sm}-\mathrm{Nd}$ dating of authigenic monazite: implications for the diagenetic evolution of the Welsh Basin. Earth Planet. Sci. Lett., 144, 421-433.

Evans, J.A., Zalasiewicz, J.A., Fletcher, I., Rasmussen, B. and Pearce, N.J.G., 2002. Dating diagenetic monazite in mudrocks: constraining the oil window? J. Geol. Soc., 159, 619-622.

Förster, H.J., 1998. The chemical composition of REE-Y-Th-U-rich accessory 
minerals in peraluminous granites of the Erzgebirge-Fichtelgebirge region, Germany, Part I: The monazite-(Ce)brabantite solid solution series. Am. Mineral., 83, 259-272.

Frantz, G., Andrehs, G. and Rhede, D., 1996. Crystal chemistry of monazite and xenotime from Saxothuringian-Moldanubian metapelites, NE Bavaria, Germany. Euro. J. Min., 8, 1097-1118.

Gabudianu Radulescu, I., Rubatto, D., Gregory, C. and Compagnoni, R., 2009. The age of HP metamorphism in the Gran Paradiso Massif, Western Alps: A petrological and geochemical study of "silvery micaschists". Lithos. 110, 95-108.

Gil-Imaz, A., 2001. La estructura de la Sierra de Cameros: deformación dúctil y su significado a escala cortical. Instituto de Estudios Riojanos, Logroño.

Goldberg, J.M., Guiraud, M., Maluski, H. and Séguret, M., 1988. Caractères pétrologiques et âge du métamorphisme en contexte distensif du bassin sur décrochement de Soria (Crétacéinférieur, Nord Espagne). C. R. Acad. Sci. Paris, 307, 521-527.

Janots, E., Engi, M., Berger, A., Allaz, J., Schwarz, J.-O. and Spandler, C., 2008. Prograde metamorphic sequence of REE minerals in pelitic rocks of the Central Alps: implications for allanite-monazite-xenotime phase relations from 250 to $610{ }^{\circ} \mathrm{C}$. J. Metamorph. Geol., 26, 509-526.

Janots, E., Engi, M., Rubatto, D., Berger, A., Gregory, C. and Rahn, M., 2009. Metamorphic rates in collisional orogeny from in situ allanite and monazite dating. Geology, 37, 11-14.

Kempe, U., Lehmann, B., Wolf, D., Rodionov, N., Bombach, K., Schwengfelder, U. and Dietrich, A., 2008. U-Pb SHRIMP geochronology of Th-poor, hydrothermal monazite: An example from the Llallagua tin-porphyry deposit, Bolivia. Geochim. Cosmochim. Acta, 72, 4352-4366.

Krenn, E. and Finger, F., 2007. Formation of monazite and rhabdophane at the expense of allanite during Alpine low temperature retrogression of metapelitic basement rocks from Crete, Greece: Microprobe data and geochronological implications. Lithos, 95, 130-147.

Lanzirotti, A. and Hanson, G.N., 1996. Geochronology and geochemistry of multiple generations of monazite from the Wepawaug Schist, Connecticut, U.S.A.: implications for monazite stability in metamorphic rocks. Contrib. Mineral. Petrol., 125, 332-340.

Lev, S.M., McLennan, S.M., Meyers, W.J. and Hanson, G.N., 1998. A petrographic approach for evaluating trace-element mobility in a black shale. J. Sedim. Res., 68, 970-980.
Ludwig, K.R., 2001. SQUID 1.02, A User's Manual. Berkeley Geochronology Center Special Publication No. 2, Berkeley, CA, USA.

Ludwig, K.R., 2003. User's Manual for Isoplot/Ex, Version 3.0, A Geochronological Toolkit for Microsoft Excel. Berkeley Geochronology Center Special Publication No. 4, Berkeley, CA, USA.

Mantilla-Figueroa, L.C., Casquet, C. and Mas, J.R., 1999. Comparación entre el metamorfismo de la Cuenca de Cameros y el de la Cuenca Aurífera de Witwatersrand (Suráfrica). Implicaciones metalogenéticas. Geogaceta, 25, 131-134.

Mas, J.R., Alonso, A. and Guimerá, J., 1993. Evolución tectonosedimentaria de una cuenca extensional intraplaca: la cuenca finijurásica-eocretácica de los Cameros (La Rioja-Soria). Rev. Soc. Geol. España, 6, 129-144.

Masuda, A., Nakamura, N. and Tanaka, T., 1973. Fine structures of mutally normalised rare-earths patterns of chondrites. Geochim. Cosmochim. Acta, 37, 239-248.

Mata, M.P. and Barbero, L., 2005. Neoformación de monacita, xenotima, florencita y apatito en rocas de bajo grado de la Cuenca de Cameros (Cordillera Ibérica). Macla, 3, 133-134.

Mata, M.P. and López-Aguayo, F., 2000. Estudio geoquímico de elementos mayoritarios, trazas y REE en las facies Weald de la Cuenca de Cameros. Bol. Soc. Esp. Min., 23, 89-106.

Mata, M.P., Casas, A.M., Canals, A., Gil, A. and Pocovi, A., 2001. Thermal history during Mesozoic extension and Tertiary uplift in the Cameros Basin, northern Spain. Basin Res., 13, 91-111.

Milodowski, A.E. and Zalasiewicz, J.A., 1991. Redistribution of rare earth elements during diagenesis of turbidite/hemipelagite mudrock sequences of Llandovery age from Central Wales. In: Developments in sedimentary provenance studies (A.C. Morton, S.P. Todd and P.D.W. Haughton, eds). Geol. Soc. Spec. Publ., 57, 101-124.

Montel, M., Foret, S., Veschambre, M., Nicollet, C. and Provost, A., 1996. Electron microprobe dating of monazite. Chem. Geol., 131, 37-53.

Pan, Y., 1997. Zircon- and monaziteforming metamorphic reactions at Manitouwadge, Ontario. Can. Mineral., 35, 105-118.

Pan, Y., Fleet, M.E. and MacRae, N.D., 1993. Oriented monazite inclusions in apatite porphyroblasts from the Hemlo gold deposit, Ontario, Canada. Mineral. Mag., 57, 697-707.

Parrish, R.R., 1990. U-Pb dating of monazite and its application to geological problems. Can. J. Earth Sci., 27, 1431-1450.

Rasmussen, B., Fletcher, I.R. and McNaughton, N.J., 2001. Dating low-grade metamorphic events by SHRIMP U-Pb analysis of monazite in shales. Geology, 29, 963-966.

Rasmussen, B., Fletcher, I.R. and Sheppard, S., 2005. Isotopic dating of the migration of a low-grade metamorphic front during orogenesis. Geology, 33, 773-776.

Rasmussen, B., Fletcher, I.R., Muhling, J.R., Mueller, A.G. and Hall, G.C., 2007. Bushveld-aged fluid flow, peak metamorphism, and gold mobilization in the Witwatersrand basin, South Africa: Constraints from in situ SHRIMP U-Pb dating of monazite and xenotime. Geology, 35, 931-934.

Rubatto, D., Williams, I.S. and Buick, I.S., 2001. Zircon and monazite response to prograde metamorphism in the Reynolds Range, central Australia. Contrib. Mineral. Petrol., 140, 458-468.

Sawka, W.N., Banfield, J.F. and Chappell, B.W., 1986. A weathering-related origin of widespread monazite in S-type granites. Geochim. Cosmochim. Acta, 50, 171-175.

Smith, H.A. and Barreiro, B., 1990. Monazite U-Pb dating of staurolite grade metamorphism in pelitic schists. Contrib. Mineral. Petrol., 105, 602-615.

Spear, F.S. and Pyle, J.M., 2002. Apatite, monazite and xenotime in metamorphic rocks. Rev. Mineral. Geochem., 48, 293-335.

Tera, F. and Wasserburg, G.J., 1972. $\mathrm{U}-\mathrm{Th}-\mathrm{Pb}$ systematics in three Apollo 14 basalts and the problem of initial lead in lunar rocks. Earth Planet. Sci. Lett., 14, 281-304.

Tischer, G., 1966. El delta Weáldico de las montañas Ibéricas Occidentales y sus enlaces tectónicos. Notas y Comunicaciones Instituto Geológico y Minero de España, 81, 53-78.

Wilby, P.R., Page, A.A., Zalasiewicz, J.A., Milodowski, A.E., Williams, M. and Evans, J.A., 2007. Syntectonic monazite in low-grade mudrocks: a potential geochronometer for cleavage formation? J. Geol. Soc. London, 164, 53-56.

Williams, I.S., 1998. U-Pb-Th geochronology by ion microprobe. In: Applications of Microanalytical Techniques to Understanding Mineralizing Processes (M.A. McKibben, W.C. Shanks III and W.I. Ridley, eds). Rev. Econ. Geol., 7, $1-35$.

Wing, B.A., Ferry, J.M. and Harrison, T.M., 2003. Prograde destruction and formation of monazite and allanite during contact and regional metamorphism of pelites: petrology and geochronology. Contrib. Mineral. Petrol., 145, 228-250.

Received 3 December 2008; revised version accepted 27 July 2009; 28 July 2009 


\section{Supporting Information}

Additional Supporting Information may be found in the online version of this article:

Table S1. Electron microprobe analysis of a selection of monazites dated of this study. The upper part of the table shows oxide composition which is given in weight percentage; $<$ d.1.: below detection limit. The lower part shows number of atoms per formula unit based on a structural formula of 3(4) oxygen atoms.

Table S2. U-Pb age results obtained for the studied monazites using SHRIMP-II. Uncertainties are given at the $1 \sigma$ level; $\mathrm{f}_{206} \%$ denotes the percentage of ${ }^{206} \mathrm{~Pb}$ that is common $\mathrm{Pb} ; \dagger$ denotes analyses not considered for the regression. Correction for common lead was made using ${ }^{238} \mathrm{U} /{ }^{206} \mathrm{~Pb}$ and ${ }^{207} \mathrm{~Pb} /{ }^{206} \mathrm{~Pb}$ ratios fol- lowing Tera and Wasserburg (1972) as outlined in Williams (1998).

Please note: Wiley-Blackwell are not responsible for the content or functionality of any supporting materials supplied by the authors. Any queries (other than missing material) should be directed to the corresponding author for the article. 